\title{
Data processing of the "Decameron" by Giovanni Boccaccio-for the 700th year of his birth
}

\author{
Tamara Bellone $^{1} \cdot$ Luigi Mussio $^{2} \cdot$ Chiara Maria Porporato $^{1}$
}

Received: 16 June 2014 / Accepted: 14 January 2016 / Published online: 3 February 2016

(C) The Author(s) 2016. This article is published with open access at Springerlink.com

\begin{abstract}
The authors, in the 700th year from the birth of Giovanni Boccaccio, intend to celebrate the event by their proper means: statistical, numerical, computing, and cartographic techniques, as used in Geomatics. However, we also mean to have an interface between Geomatics and Humanistics for hybridation of different areas.
\end{abstract}

Keywords Boccaccio's geography $\cdot$ Decameron $\cdot$ Geomatics

\section{Introduction}

The authors, in the 700th year from the birth of Giovanni Boccaccio, intend to celebrate the event by their proper means: statistical, numerical, computing, and cartographic techniques, as used in Geomatics. As the Decameron novels record time, places, and itineraries, it is easy to put in evidence the latter (with further evolution of synthesis of results).

Most of the medieval maps have a general "TO" shape. The "O" means the outer ring of waters, the ocean, which encloses

Tamara Bellone

tamara.bellone@polito.it

Luigi Mussio

luigi.mussio@polimi.it

Chiara Maria Porporato

chiara.porporato@polito.it

1 DIATI, Politecnico di Torino, Corso Duca degli Abruzzi, 24, 10129 Turin, Italy

2 DICA, Politecnico di Milano, Piazza Leonardo da Vinci, 32, 20133 Milan, Italy the lands; the " $\mathrm{T}$ " is the general shape of the three continents, as related to the three sons of Noah. Indeed, in the Middle Age, the Earth was thought of as a globe mainly covered with water, with a number of islands comparatively small, a part of which was Oekoumene. So, it was thought as possible a plane representation of Oekoumene. This type of maps is clearly related to the views of Augustine about the City of God: evidently, the will of God has placed Christians at the centre of Oekoumene, as non-Christian peoples are relegated in outer spaces, even at the boundary of non-human beings.

Boccaccio's world, from the cartographic viewpoint, is not the one of TO maps, but the one of portolanos for travelers and merchants. Boccaccio's world is the one of Florentine merchants. Ptolemy's Geographia had been translated from Greek to Arabian language in the ninth century; later, a Latin translation was made available in the early fourteenth century. Obviously, Boccaccio could not know about Geographia; however, in the period of Neapolitan apprenticeship, he was very interested in Mathematics and Astronomy, having as instructors Andalò del Negro and Paolo dell'Abaco, respectively. So, Boccaccio also wrote about Geography (De Canaria et insulis reliquis ultra Hispaniam in Oceano noviter repertis (1342) and De montibus, silvis, fontibus, lacubus, fluminibus, stagnis seu paludibus et de diversis nominibus maris (1374).

However, we also mean to have an interface between Geomatics and Humanistics, for hybridation of different areas.

Statistical and probabilistic methods, as presently employed in the field of social sciences, have been greatly enhanced by a larger availability of computation facilities in the last decades. For Linguistics, statistical methods have come into use in early decades of the past century (Markov 1913)). The great pupil of Čebyšëv examined the first 20,000 characters of Puškin's "Evgenij Onjegin" with attention paid to the probability of alternance vowel/consonant. Later, Markov applied the same statistical technique to Aksakov's 
"The childhood of Bogrov the grandson." Many other scholars, after him, were interested to find out the real authors or the text analysis.

The famous method of "Markov's chains" was extended to many fields.

In the present paper, the authors will use statistical and geomatical techniques to test geographical knowledge of Boccaccio, as shown in the travels described in the Decameron novels.

(Branca 1992) notes that geographical assessment of location is pursued with remarkable precision and in one of the most remarkable issues of "Boccaccio's realism."(Greppi 2010) has resumed geographical knowledge of Boccaccio in a dedicated dictionary. Also, the Italian IGM (Istituto Geografico Militare) managed in 2005 a conference about Boccaccio as a geographer, with a contribution of the medievalist Franco Cardini.

A visualization of Boccaccio's world has been conceived starting with "density-equalizing maps," a method due to (Gastner and Newman 2004). Worldmapper is a website which contains a number of these maps: each map is related to a particular subject. Tobler was an early user of cartograms, especially the "value-by-area" variety, in order to communicate spatial properties other than position and size in space (Tobler 1996).

\section{The structure of Decameron}

The Decameron (Boccaccio 2012) begins with the flight of ten young people (seven girls and three boys) from plaguestricken Florence in 1348. They retire to a rich, well-watered countryside, where, in the course of a fortnight, each member of the party has a turn as king or queen over the others, deciding in detail how their day shall be spent and directing their leisurely walks, their outdoor conversations, their dances and songs, and, above all, their alternate storytelling. This storytelling occupies 10 days of the fortnight (the rest being set aside for personal adornment or for religious devotions); hence, the title of the book itself, Decameron. The stories thus amount to 100 in all. Each of the days, moreover, ends with a canzone (song) for dancing sung by one of the storytellers (from: Encyclopedia Britannica).

So, the structure of Decameron consists of a narrative framework, in which the author tells the story of the "brigade" escaping from Florence in the villa, and a hundred short stories divided in 10 days.

The first day, the theme is free (Pampinea is the Queen).

The other themes are

- the importance of fortune to achieve goal (Queen: Filomena)

- the role of ingenuity for succeeding (Queen: Neifile)
- the love stories that end sadly (King: Filostrato)

- the love stories that end happily (Queen: Fiammetta)

- the effectiveness of witty responses (Queen: Elissa)

- the mockery of wives to husbands (King: Dioneo)

- jokes of any kind (Queen: Lauretta)

- human vices (Queen: Emilia)

- liberal and magnificent actions (King: Panfilo)

Each storyteller is a determined character, for example, Fiammetta is passionate and jealous, whereas Philostratus is melancholic and Pampinea is an intellectual woman, and so on. In this paper, the authors study Boccaccio's geography. The entire list of places and travels of the Decameron novels is written in Appendix 2.

\section{Concerning representation: diffusion-based method for density-equalizing maps}

Traditional thematic mapping, unlike standard reference maps which only show natural features, highlights the spatial distribution of a given item or of a specific characteristic (temperature, agricultural-related items, population density, etc.). It also shows variations in data over time, such as the history of a migration or the spread of a disease.

In short, a thematic map combines geographical data and the time variable linked to the relevant items. In addition, it makes plain relationships among the most important features and aids correlation analysis of geographical data.

In the actual creation of any thematic map, once both a specific physical area and a suitable cartographic projection have been selected (usually from equivalent projections, which preserve dimensional stability of the tested area), it is fundamental to perform an analysis of a number of sets of statistical data and to choose an appropriate method for representation of the variables. Color, for instance, is a major element in producing clear and effective maps.

However, the last few decades have seen an increase in the use of cartograms in which the tested area is not stable but may be distorted in order to convey information relating to the feature itself (anamorphic maps). Indeed, an anamorphic map is easier to understand and provides a better overview of a specific geographical question.

Many scholars have generated cartograms in which the dimensions of a given region would be proportionate to its population or to any other feature (or a statistical variable). However, this type of graphical rendering of statistical data makes it hard, at times, to recognize the areas under examination, as the constraints for assembling adjacent regions produce distortions, which may result in the map being difficult to use. Moreover, drawing such maps is a difficult computational task, requiring considerable time for calculations to be performed. 
In view of this fact, M.T. Gastner and M.C. Newman of the Physics Department and Center for the Study of Complex Systems of the University of Michigan, in Ann Arbor, have presented a simple algorithm based on Elementary Physics, which allows easy-to-read cartograms to be produced (modified from (Gastner and Newman 2004)). The algorithm is based on the theory of diffusion, and for this reason, the cartograms are also known as "diffusion-based" or "anamorphic maps."

For a distribution-based cartogram, distribution must be necessarily uniform, and after resizing areas so that they are proportionate to the variable, by definition, density is equal everywhere.

Given a particular distribution, one way to create a cartogram is to let the elements "flow" from areas of greater density to areas of lesser density, with the aim of equalizing overall density, as in any diffusion process of Elementary Physics (it can be easily proven that linear diffusion is simply a density equalization).

Moreover, since areas of interest have boundaries or coastlines (beyond which density is unknown or insignificant), interest often regards particular areas of the globe and not the entire globe itself. Here, a neutral threshold condition is applied, ensuring that the area of interest floats in a kind of sea of uniform densities, equal to the average of the densities of the entire area of interest (the tested area should remain constant during the diffusion process).

These intuitive considerations complete the description of the method used (the algorithm implementation, in contrast, requires computing operations which must be carried out in a relatively short time). Be this as it may, this remains a highly interesting tool for the representation and analysis of geographic data.

\section{Places of the "heart"1}

\begin{tabular}{llll}
\hline $\begin{array}{c}\text { Absolute } \\
\text { frequency }\end{array}$ & $\begin{array}{c}\text { Places of } \\
\text { the heart }\end{array}$ & $\begin{array}{c}\text { Absolute } \\
\text { frequency }\end{array}$ & $\begin{array}{c}\text { Places of } \\
\text { the heart }\end{array}$ \\
\hline 1 & Abruzzo & 1 & $\begin{array}{c}\text { Castellammare } \\
\text { di Stabia } \\
\text { Cathai (today } \\
\text { China) }\end{array}$ \\
1 & $\begin{array}{c}\text { Acquamorta (present- } \\
\text { day Monte } \\
\text { di Procida) }\end{array}$ & 1 & Cephalonia \\
1 & $\begin{array}{l}\text { Acri } \\
\text { Agrigento }\end{array}$ & 1 &
\end{tabular}

\footnotetext{
${ }^{1}$ The places of the heart is a common locution, recently adopted by thematic cartography to mean "preferences." Places are listed according to Italian alphabetical order (as Boccaccio wrote them).
}

Certaldo, Garbo (province of Florence)

Chiarenza

(Romania,

Peloponnese)

$\begin{array}{lll}\text { Alexandria } & 1 & \text { Chios } \\ \text { Amalfi } & 6 & \text { Cyprus }\end{array}$

Anagni

Classe (province of Ravenna)

Ancona

Antiochia

Cluny

Corfu (formerly island of Gurfo)

Antwerp

Aragona

Cornwall

Corsignano (hamlet of Pienza)

Arezzo

Constantinople (sea before)

Argo (Peloponnese) $\quad 1 \quad$ Cremona

Armenia

Assisi

Crete

deserts of Thebais (Egypt)

Asti

Athens

Avignone

Babylon

Barberia

Barcelona

Barletta

Benevento

Berlinzone

(Land of

Bengodi)

Bitonto

Bologna

Borgo San Lorenzo

Burgundy

Brescia

Brindisi

Bruges

Buonconvento (province

of Siena)

Calais

Campi Bisenzio

Candia (Island of Crete)

Cappadocia

Capsa (Tunisia)

Carthage

Castel Guglielmo (province of Rovigo)

Ischia

Laiazzo (today Ayas in Turkey)

Lamporecchio (province of Pistoia)

Laterina (province of Arezzo)
Aegina

Faenza

Famagosta

Fano

Ferrara

Flanders

Fiesole

Florence

Mouth of the Magra

Forlimpopoli

France

Friuli

Gaeta

Weles

Genoa

Jerusalem

Gharb (Island of Malta)

Granada

Gascony

Imola

India

The Hell

England

Ireland

Puglia (Apulia)

(The) Purgatory

Radicofani (province of Siena)

Ravello 


\begin{tabular}{|c|c|c|c|}
\hline 1 & Lerici & 2 & Ravenna \\
\hline 2 & Lipari & 1 & Reggio Calabria \\
\hline 1 & Livorno & 1 & Rimini \\
\hline 3 & Lombardy & 3 & Rhodes \\
\hline 3 & London & 11 & Rome \\
\hline 3 & Lunigiana & 2 & Romagna \\
\hline 1 & Majorca & 1 & $\begin{array}{l}\text { Rossiglione } \\
\text { (Rossillon, } \\
\text { France) }\end{array}$ \\
\hline 1 & Mar Egeo & 4 & Salerno \\
\hline 1 & Marca d'Ancona & 2 & Saluzzo \\
\hline 1 & Marseilles & 2 & Sardinia \\
\hline 2 & Messina & 1 & Scalea \\
\hline 3 & Milan & 1 & Scotland \\
\hline 1 & $\begin{array}{l}\text { Molese (the area } \\
\text { of Mola di Bari) }\end{array}$ & 7 & Sicily \\
\hline 1 & Modena & 5 & Siena \\
\hline 2 & Monaco & 1 & Smirne \\
\hline 1 & Monferrato & 2 & Spain \\
\hline 1 & Montpellier & 1 & Stanford \\
\hline 1 & Mugello & 1 & Susa (in Tunisia) \\
\hline 8 & Naples & 1 & The Holy Land \\
\hline 1 & Narbonne & 1 & $\begin{array}{l}\text { Truffia, Buffia } \\
\text { and Menzogna } \\
\text { Territory }\end{array}$ \\
\hline 1 & Paphos & 1 & $\begin{array}{l}\text { Ticino (river near } \\
\text { Pavia) }\end{array}$ \\
\hline 6 & Palermo & 1 & $\begin{array}{l}\text { Torrenieri (a hamlet } \\
\text { of Montalcino) }\end{array}$ \\
\hline 1 & Paradise & 5 & Tuscany \\
\hline 15 & Paris & 1 & Trani \\
\hline 5 & Pavia & 2 & Trapani \\
\hline 1 & Persia & 1 & $\begin{array}{l}\text { Tresanti (province } \\
\text { of Florence) }\end{array}$ \\
\hline 4 & Perugia & 1 & Treviso \\
\hline 2 & Pisa & 2 & Tunisia \\
\hline 2 & Pistoia & 1 & Udine \\
\hline 1 & Pontremoli & 1 & Ustica \\
\hline 1 & Ponza & 1 & $\begin{array}{l}\text { Valbona (a hamlet } \\
\text { of Berceto or } \\
\text { Collagno, province } \\
\text { of Parma or } \\
\text { province of } \\
\text { Reggio Emilia) }\end{array}$ \\
\hline 3 & Prato & 1 & Valdarno \\
\hline 1 & Procida & 3 & Venice \\
\hline 2 & Provence & 2 & Verona \\
\hline
\end{tabular}

Needless to say, Florence comes out on top, followed, some way behind, by Paris (with roughly a third of the mentions of Florence) and by

- Rome

- Alexandria, Bologna, Genoa, Naples

- Cyprus, Palermo, Sicily

- Pavia, Siena, Tuscany

- Crete, Perugia, Salerno (with between nearly one quarter to one tenth of mentions, approximately), with at last many items, triple, double, or single. Some absences are noteworthy:

- in Tuscany, Lucca (a town of tricksters, in Dante's Divine Comedy, Hell, canto XXI)

- in the Emilia Romagna region, Parma, Piacenza and Reggio Emilia

- in Veneto, Padua and Vicenza (besides Trieste in the Venezia Giulia region)

- in Lombardy, Bergamo, Como, Crema, Cremona, Lodi, Monza, and Mantova (that is, only Brescia, Milan, and Pavia)

- in Piedmont, all but Monferrato, Asti, and Saluzzo (and especially Turin)

- in Apulia, Bari, Lecce, and Taranto

- in Sicily, Catania, Enna, and Syracuse

Other facts are remarkable:

- Boccaccio's geography is limited to Europe, the Mediterranean Sea, North Africa, and Near East, going into Asia and reaching Armenia, Persia, India, and China, though making no mention of Tibet, or Siam (today's Thailand), or Japan, which are in turn mentioned by Polo

- Africa (Saharan and Sub-Saharan) is never cited, despite the growing concern for its circumnavigation, as evidenced by the unsuccessful journey of the Vivaldi brothers from Genoa as well as by the imaginary journey of Dante's Ulysses (Comedy, The Hell, canto XXVI)

- In Europe, no mention for German and for Slavonic worlds (in that age, only Scandinavia and Russia could be regarded as marginal): of its peripheral areas, all ports of British Isles are recorded, as is Ireland, though not Portugal

- In the Mediterranean Sea, almost all its islands are mentioned, though not Elba (nor any other small islands of Tuscany), nor even Corsica, despite these being the nearest to Florence and Tuscany ${ }^{2}$

- Two places are purely imaginary: the Terre di Menzogna (the Lands of Lies) and the Lands of Berlinzone

- Three novels deal with Hell, ${ }^{3}$ Purgatory, and Paradise (along the lines of the cantos in the Divine Comedy, ${ }^{4}$

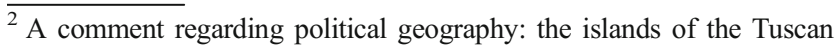
archipelago never belonged to Tuscany, before the Congress of Vienna (1815).

${ }^{3}$ Descents to Hades are recorded in Odyssey and Aeneid, as well as constituting the first part of the Divine Comedy.

${ }^{4}$ Dante's Comedy is later quoted at length by Galilei himself, when, in 1588, he gave two lectures at the Florentine Academy on the subject of the build, shape, and size of Dante's Inferno, developed from studies by Antonio Manetti, a mathematician and architect from Florence of the fifteenth century, concerning the site, shape, and measure of Inferno and also the size of giants and of Lucifer, as shown by the testimony (not absolutely consistent) of the humanist Cristoforo Landino and of the Renaissance poet Girolamo Beniveni, both Florentines.
} 
and the garden in the Decameron Cornice resembles the Paradise on Earth depicted in Dante's masterpiece

- Nothing is said about travels to the Moon ${ }^{5}$

Here follow some images showing

the frequency diagram of the so-called places of the heart

(Figs. 1 and 2)

- the geographical location of the said places of the heart in Italy (in two different depictions, natural and anamorphic $^{6}$ ) (Fig. 3a, b)

- the location of the same places of the heart in Boccaccio's world (with both modes of representation) (Figs. 3a and 4b).

As far as Boccaccio's world is concerned then, it is confined, apart from India and China, solely to a part of Europe, to the Mediterranean Sea, and to North Africa and the Near East. For this reason too, a normal map (with its meridians and parallels) would include large areas with no involvement in the novels (since only Italy, France, and a few other countries are spoken of, the overall result would make the map difficult to read) (Figs. 3a and 4a). Notice how in the anamorphic representation some Italian regions, e.g., Sardinia, Apulia, and Calabria, are greatly reduced. This type of cartographic representation immediately highlights that in these regions are present only a few places of the heart or none.

When, however, all the territories (or proper groupings of the same, if too small singularly) are given at a unitary (and non-zero) weight, and one unit is added to all counties involved, so as not to distort the result, the resulting sum gives an anamorphic chart much less deformed than the natural map and hence much easier to read. Moreover, this procedure does not alter data, but simply transfers the digits representing them, that is a shift of origin (a standard procedure, together with the change of scale, in cartography) (Figs. $3 b$ and $4 b$ ). Notice how the anamorphic representation shows the Italian areas more warped than the rest of the Mediterranean zones because of the same consideration of the previous figure. Indeed, the characteristic deformation of the anamorphic representation strictly depends on the involved geographic zone.

Further proof of the non-randomness of the places of the heart is provided by Boccaccio himself, as seen if we examine the giornate (days), in the columns, and the order of narration

\footnotetext{
$\overline{{ }^{5} \text { Fanciful voyages to the Moon are also described in antiquity by Lucian }}$ from Samosata. In "Orlando Furioso" (by Ludovico Ariosto), Astolfo too goes to the Moon.

${ }^{6}$ Anamorphic maps are well suited to highlighting the places of the heart. Indeed, Florence is scarcely visible on a "natural" map (being comparatively small in area) but is clearly indicated on an anamorphic map of Italy.
}

of the novels, in the rows, by the ten storytellers, whose names-1 to 10 - are in alphabetical order (Table 1 and Table 2). Indeed, connection analysis, performed by calculating the contingencies and Bonferroni indices, by itself shows the almost complete independence among giornate (days of tales) and the order of narration. It must be borne in mind, moreover, that the contingencies and Bonferroni indices merely serve to reject independence, computing the differences between double frequencies and the product of corresponding marginal frequencies (equality of these values is the condition of independence). Elementary computation gives rather low values for all Bonferroni's indices (unilateral and bilateral). ${ }^{7}$

\section{The travel routes}

The list of travel routes will show the basic unity of Boccaccio's world (Italian and otherwise), detecting in

\footnotetext{
${ }^{7}$ In a two-dimensional statistical distribution, showed by means of a double-entry table, a generic row of the table describes a conditional distribution of $Y$, that is, represents the way in which the attribute $Y$ is distributed between individuals of the population characterized by a single value of attribute $X$. Similarly, a generic column represents the conditional distribution of the attribute $X$.

We define

$f_{\mathrm{ij}}=$ joint relative frequencies

$q_{\mathrm{i}}=$ marginal frequencies of $X$

$p_{\mathrm{j}}=$ marginal frequencies of $Y$

Bonferroni's indices suggest the connection between the two variables:

$c_{\mathrm{ij}}=f_{\mathrm{ij}}-p_{\mathrm{j}} q_{\mathrm{i}}$ is the contingency,

$c_{0}=\frac{1}{2} \sum_{i j}\left|c_{i j}\right| \beta_{x}=\frac{c_{0}}{1-\sum_{i j} q_{i}^{2}} \beta_{y}=\frac{c_{0}}{1-\sum_{i j} p_{j}^{2}} \beta_{0}=\sqrt{\beta_{x} \beta_{y}} \beta_{-1}$

$=\frac{2 \beta_{x} \beta_{y}}{\beta_{x}+\beta_{y}}$
}

where $\beta_{x}$ and $\beta_{y}$ are the Bonferroni unilateral indices and $\beta_{0}$ and $\beta_{-1}$ are bilateral Bonferroni's ones. If the absolute frequencies are used, as in our case, the formulas are modified:

$$
c_{0}=\frac{1}{2 N^{2}} \sum_{i j}\left|N_{i j}-P_{i} Q_{j}\right| \beta_{x}=\frac{c_{0}}{N^{2}-\sum_{i j} Q_{i}^{2}} \beta_{y}=\frac{c_{0}}{N^{2}-\sum_{i j} P_{j}^{2}}
$$

where $N$ is the size of the sample, $N_{\mathrm{ij}}$ are the joint absolute frequencies, and $Q_{\mathrm{i}}$ and $P_{\mathrm{j}}$ are the absolute marginal frequencies of $X$ and $Y$.

$$
\begin{aligned}
\beta_{x} & =\frac{c_{0}}{N^{2}-\sum_{i j} Q_{i}^{2}}=\frac{58,575}{302,500-32,086}=0 ., 21666 \cong 0 ., 22 \beta_{y} \\
& =\frac{c_{0}}{N^{2}-\sum_{i j} P_{j}^{2}}=\frac{58,575}{302,500-30,250}=0 ., 21555 \cong 0 ., 22
\end{aligned}
$$

And consequently $\beta_{0}=0.22$ 
it a unique cluster, albeit, to varying degrees, a jagged one.

\begin{tabular}{|c|c|c|}
\hline \multirow[t]{5}{*}{ 1st day } & Tale & Route \\
\hline & 1 & A: Prato-Burgundy; B: Burgundy-Tuscany \\
\hline & 2 & Paris-Rome-Paris \\
\hline & 5 & France-Monferrato-Genoa \\
\hline & 9 & Gascony-The Holy Land-Cyprus \\
\hline \multirow[t]{11}{*}{ 2nd day } & Tale & Route \\
\hline & 1 & Florence-Treviso-Florence \\
\hline & 2 & Asti-Bologna-Ferrara-Asti \\
\hline & 3 & $\begin{array}{l}\text { A: Florence-London-Florence; } \\
\text { B: Florence-London-Rome- } \\
\text { Florence-London-Florence }\end{array}$ \\
\hline & 4 & $\begin{array}{l}\text { Ravello-Cyprus-Constantinople- } \\
\text { Cefalonia-Corfü-Trani-Ravello }\end{array}$ \\
\hline & 5 & Perugia-Rome-Perugia \\
\hline & 6 & $\begin{array}{l}\text { A: Palermo-Lipari-Ponza-Lunigiana- } \\
\text { Lerici-Palermo; B: Palermo-Lipari- } \\
\text { Ponza-Genoa-Lunigiana-Lerici- } \\
\text { Palermo; C: Palermo-Lipari-Ponza- } \\
\text { Lerici-Palermo }\end{array}$ \\
\hline & 7 & $\begin{array}{l}\text { Alexandria-Majorca-Peloponnesus- } \\
\text { Athens-Egina-Chios-Rhodes-Cyprus- } \\
\text { Famagosta-Alexandria-Gharb }\end{array}$ \\
\hline & 8 & $\begin{array}{l}\text { Paris-Calais-London-Weles-Ireland-- } \\
\text { Weles-London-Paris }\end{array}$ \\
\hline & 9 & $\begin{array}{l}\text { A: Genoa-Paris-Genoa-Alexandria-Genoa; } \\
\text { B: Genoa-Alexandria-Genoa }\end{array}$ \\
\hline & 10 & A: Pisa-Monaco; B: Pisa-Monaco-Pisa \\
\hline \multirow[t]{8}{*}{ 3rd day } & Tale & Route \\
\hline & 1 & $\begin{array}{l}\text { Lamporecchio (province of Pistoia)-Florence- } \\
\text { Lamporecchio (province of Pistoia) }\end{array}$ \\
\hline & 3 & Florence-Genoa-Florence \\
\hline & 4 & Paris-Florence \\
\hline & 5 & Pistoia-Milan-Pistoia \\
\hline & 7 & Florence-Ancona-Cyprus-Ancona-Florence \\
\hline & 9 & $\begin{array}{l}\text { A: Rossillon (in France)-Paris-Florence; B: } \\
\text { Rossillon (in France)-Paris-Rossillon } \\
\text { (in France)-Florence }\end{array}$ \\
\hline & 10 & $\begin{array}{l}\text { Capsa (in Tunisia)-deserts of Thebais } \\
\text { (in Egypt)-Capsa (in Tunisia) }\end{array}$ \\
\hline
\end{tabular}

\begin{tabular}{|c|c|c|}
\hline \multirow[t]{7}{*}{ 4th day } & Tale & Route \\
\hline & 2 & Imola-Venice \\
\hline & 3 & $\begin{array}{l}\text { A: Marseilles-Crete; B: Marseilles- } \\
\text { Crete-Rhodes }\end{array}$ \\
\hline & 4 & $\begin{array}{l}\text { A: Messina-Ustica-Messina; } \\
\text { B: Tunisia-Ustica }\end{array}$ \\
\hline & 5 & Messina-Naples \\
\hline & 8 & Florence-Paris-Florence \\
\hline & 10 & Salerno-Amalfi-Salerno \\
\hline \multirow[t]{6}{*}{5 th day } & Tale & Route \\
\hline & 1 & $\begin{array}{l}\text { A: Cyprus-Rhodes-Crete-Cyprus; } \\
\text { B: Rhodes-Crete-Rhodes }\end{array}$ \\
\hline & 2 & $\begin{array}{l}\text { A: Lipari-Tunisia-Lipari; B: Lipari-Susa } \\
\text { (in Tunisia)-Tunisia-Lipari }\end{array}$ \\
\hline & 3 & Rome-Anagni-Rome \\
\hline & 5 & Fano-Faenza \\
\hline & 6 & A: Ischia-Palermo; B: Procida-Ischia-Palermo \\
\hline
\end{tabular}

A: Armenia-Trapani-Armenia; B: ArmeniaTrapani-Rome-Trapani-Armenia; C: Trapani-Armenia

A: Ravenna-Classe (province of Ravenna); B: The Hell-Classe (province of Ravenna)

\begin{tabular}{|c|c|c|}
\hline \multirow[t]{4}{*}{ 6th day } & Tale & Route \\
\hline & 2 & Rome-Florence \\
\hline & 5 & Mugello-Florence \\
\hline & 10 & $\begin{array}{l}\text { Venice-Florence-(imaginary) countries of } \\
\text { Truffia, Buffia, and Menzogna-Florence }\end{array}$ \\
\hline \multirow[t]{4}{*}{ 7th day } & Tale & Route \\
\hline & 1 & Florence-Fiesole \\
\hline & 7 & Paris-Bologna \\
\hline & 10 & Siena-The Hell-Siena \\
\hline \multirow[t]{4}{*}{ 8th day } & Tale & Route \\
\hline & 1 & Milan-Genoa-Milan \\
\hline & 7 & Paris-Florence \\
\hline & 10 & $\begin{array}{l}\text { Florence-Salerno-Palermo-Naples-Palermo- } \\
\text { Florence-Ferrara }\end{array}$ \\
\hline \multirow[t]{4}{*}{ 9th day } & Tale & Route \\
\hline & 4 & $\begin{array}{l}\text { A: Marca d'Ancona-Siena-Buonconvento } \\
\text { (province of Siena)-Siena; B: Siena- } \\
\text { Buonconvento (province of Siena)- } \\
\text { Corsignano (hamlet of Pienza) }\end{array}$ \\
\hline & 9 & $\begin{array}{l}\text { Laiazzo (today Ayas in Turkey)-Antiochia- } \\
\text { Jerusalem-Antiochia-Laiazzo (today } \\
\text { Ayas in Turkey) }\end{array}$ \\
\hline & 10 & Barletta-Bitonto \\
\hline \multirow[t]{8}{*}{ 10th day } & Tale & Route \\
\hline & 1 & Spain-Tuscany \\
\hline & 2 & $\begin{array}{l}\text { A: Radicofani (province of Siena)-Rome; } \\
\text { B: Cluny-Rome-Radicofani (province } \\
\text { of Siena)-Rome }\end{array}$ \\
\hline & 4 & Bologna-Modena-Bologna-Modena-Bologna \\
\hline & 6 & $\begin{array}{l}\text { A: Florence-Castellammare di Stabia; } \\
\text { B: Castellammare di Stabia-Naples-Apulia }\end{array}$ \\
\hline & 8 & Rome-Athens-Rome \\
\hline & 9 & $\begin{array}{l}\text { A: Alexandria-Milan-Pavia-Alexandria; } \\
\text { B: Pavia-Genoa-Acri-Alexandria-Pavia } \\
\text { (by magics) }\end{array}$ \\
\hline & 10 & Saluzzo-Bologna-Saluzzo \\
\hline
\end{tabular}

In the images, a single cluster can be recognized, even if variously indented. Switching from the connection matrix (Fig. 5) (putting places in alphabetical order, while keeping Florence at the bottom of the list and dissecting it, in order to highlight its centrality) to the reordered one (Fig. 6) (by graph theory), having recognized some regional affiliations (Florence and Pisa in Tuscany, Fano in the Marche region, Bitonto in Apulia, Jerusalem in the Holy Land, and the deserts of Thebaid in Egypt), the clearly resulting sole cluster representing Boccaccio's world stands out.

Beware: the images, output of a graph computational program, are to be read in a qualitative way, in order to show the substantial unity of Boccaccio's world. The 
Fig. 1 The places of the heart in Italy of the Decameron: a frequency diagram

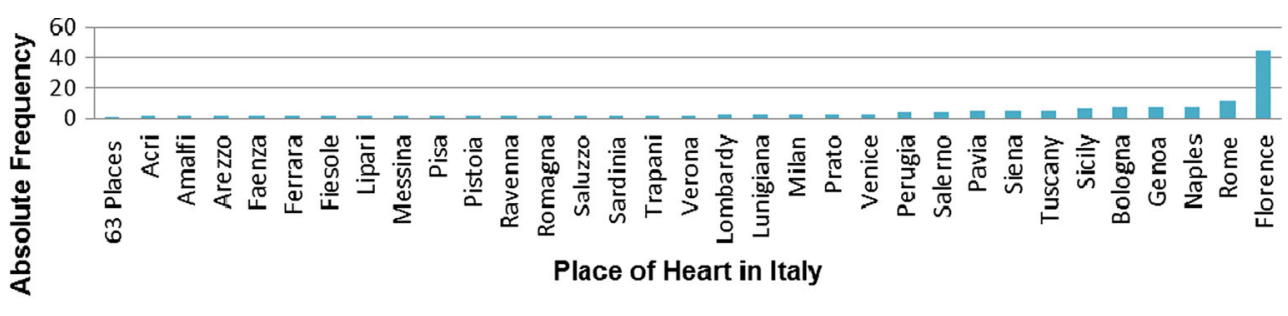

n 63 Places with absolute frequency value $=1$ places are labeled according to (Italian) alphabetical order form Acri (no. 1) to Venice (no. 90). Figure 5 shows the correspondent connection matrix ${ }^{8}$, and Fig. 6 represents the same matrix reordered using an ordering algorithm of Cuthill-McKee type for sparse matrices ${ }^{9}$ (George and Liu 1981).

\section{Final remarks}

The 700th year from the birth of Boccaccio was a useful pretext to investigate how Geomatics could approach the study of a humanistic topic. Since Decameron novels deal with place, itineraries, and travels, they proved to be an ideal study case to verify the hybridation among Geomatics and Literature. Thematic maps show a synthetic information about the travels described in the literary work, and they give in a clear image the amplitude of geography of Boccaccio's novels (i.e., the Mediterranean area).

Moreover, the anamorphic description of the travels allows to give with the geographic information also the weight of the information itself. A future work could concern the travel times of the analyzed travel routes.

The authors hope that this could be one of many other "mixed studies" among science not similar but, in some way, complementary.

Our analysis can be summarized in the words of (Branca 1992): "a new World Atlas opens from novel to novel." But the center of these worlds is always Florence; moreover, for some reasons, Eastern Europe, beyond Constantinople, is quite ignored.

\footnotetext{
${ }^{8} \mathrm{~A}$ connection matrix (or adjacency matrix) is a square matrix used to represent a finite graph. The elements of the matrix indicate whether pairs of vertices are adjacent or not in the graph: the adjacency matrix is a $(0,1)$ matrix.

${ }^{9}$ The Cuthill-McKee class of algorithms relabels the vertices of the graph, in order to reduce the bandwidth of the adjacency matrix. Indeed, by an appropriate renumbering of the vertices, it is often possible to obtain a matrix with a smaller bandwidth. Notice that a well-ordered matrix also helps identify clusters, paths, etc.
}

\section{Appendix 1: Anamorphosis history}

The following text is a brief history of anamorphosis, a word first used in the seventeenth century, although the process itself had been experienced long before.

In fact, perspective, discovered in the fifteenth century, offers the third dimension and, while it is often taken to represent a type of realism, it remains an artifice and, as such, it lends itself to different uses, including the creation of optical illusions or even deformations of ordinary reality. Indeed, the distinction between art-copy and art-evocation goes back to Plato, with reflections on the difference between object and vision fascinating scholars, philosophers, and artists throughout history.

Lorenzo Ghiberti, Tommaso di ser Giovanni di Mone Cassai, known as Masaccio, Leon Battista Alberti, Piero della Francesca, Leonardo da Vinci, Albrecht Dürer, and Jacopo Barozzi da Vignola are the best exponents of compositions and artifices based on Optics and Geometry.

In the history of art, of the variety of ways of representing three dimensionality on a flat surface, perspective is often taken to be that closest to reality, though also as being a symbolic technique like any other. Ernst Gombrich and Erwin Panofsky, respectively, are major proponents of these two opposing views: the former (Gombrich 1979) bases his ideas on the psychology of perception (Gestalt), developed from Husserl and from Kant's theory of knowledge: Kant states that Euclidean space is a priori human knowledge (obviously, he knows nothing of new aspects of non-Euclidean geometries, discovered long after his lifetime).

Panofsky, in contrast, works from theories about human vision: indeed, as Kepler already knew in his day, some straight lines may be perceived as curves, due to the curvature of our retinae (Odifreddi 2011). In this case, Euclidean space a priori is left behind: if any space is an a priori concept for the perception of the world, then this may be an elliptic space (specifically a spherical one) or a hyperbolic one. Panofsky may be right in this (taking the classical perspective to be a symbolic process): it is useful to remember what contemporaries thought of the early works of Van Gogh, Degas, or Cézanne, as these masters depict what they really see, far removed from what they would paint following the classical rules of perspective (Panofsky 1991). Consequently, a certain 
Fig. 2 The places of the heart in Italy plotted in function of the kilometric distance from Florence

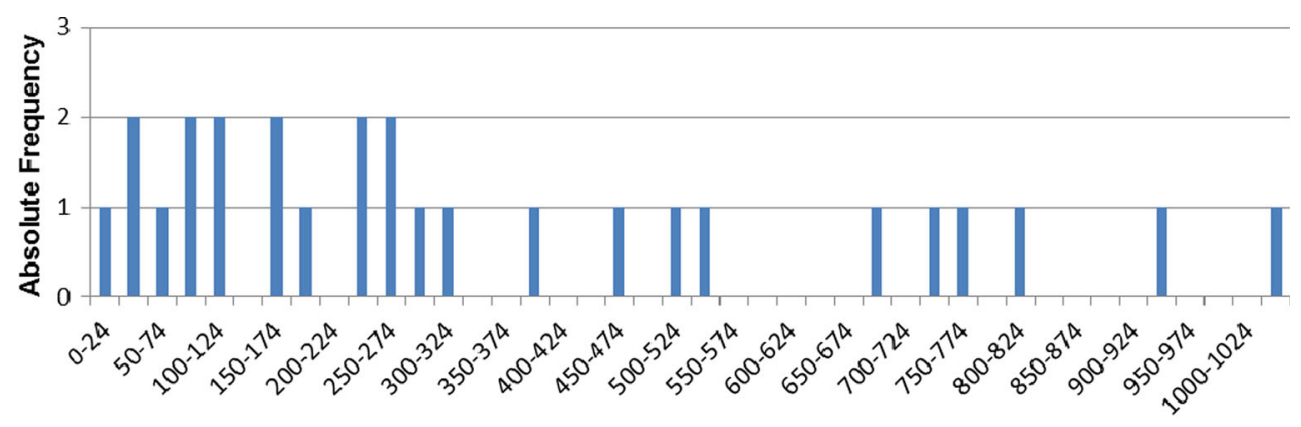

Classes of kilometric distances from Florence degree of rejection on the part of the general public was to be expected at the time, because the rules of perspective had already penetrated the public unconscious (Odifreddi 2011)).

According to (Kemp 1999)) both views are valuable: different types of perspective do exist: an image on the retina is indeed a central one, but only at horizontal middle distances; images are, in contrast, deformed for objects which are either very close or very distant. Artists in antiquity, indeed, used deformations for specific purposes: a statue by Fidias, which would appear unnatural at ground level, could be appreciated in all its splendor when placed at the exact height envisaged by the sculptor (even if this caused Plato to object since the "corrections" distanced the work from reality).

a

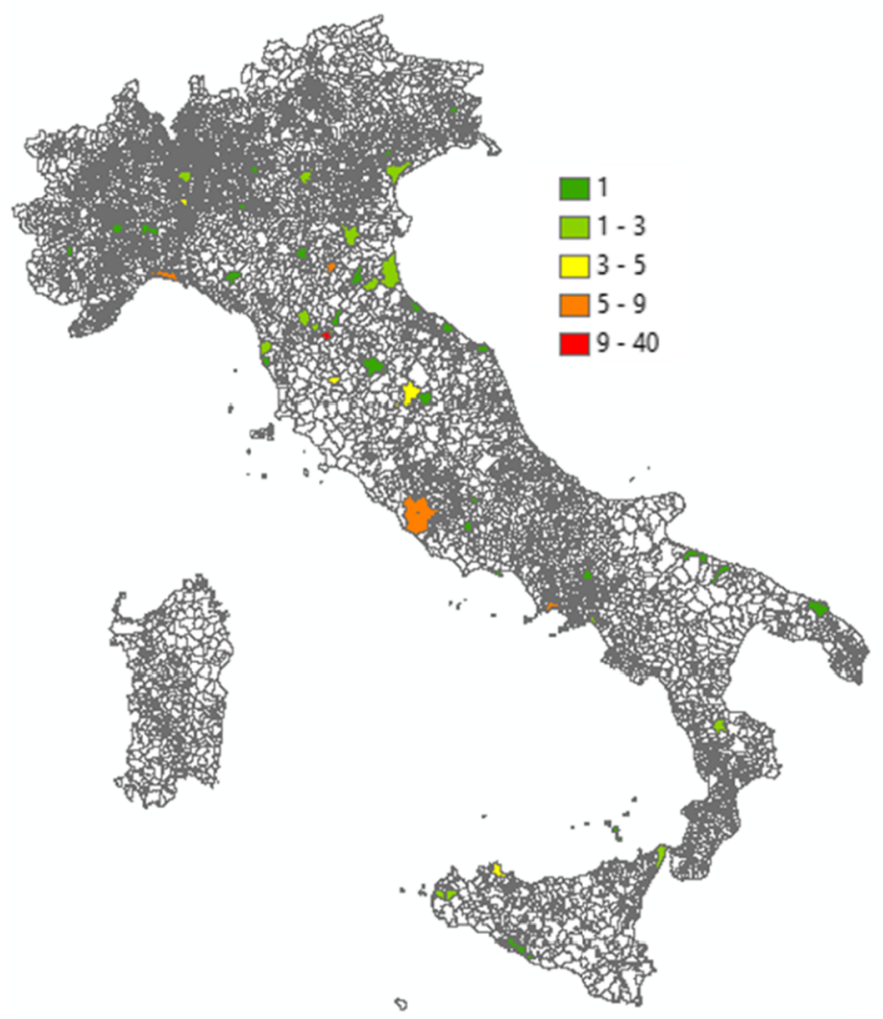

Early interest in anamorphosis is associated with Leonardo's experience of examining issues posed by distortion at the periphery of vision concerning the necessity to paint curved surfaces when the viewpoint is oblique (Gian Paolo Lomazzo describes these as problems of "inverse perspective" (Lomazzo 1973)).

Anamorphic applications become more frequent towards the end of the sixteenth century, and while the first anamorphic pictures come from North Europe, theoretical studies are largely developed in Italy, by Leonardo and others.

"Costruzione legittima" is one of two applications of perspective, since the system can work in both ways. Indeed, a square in perspective becomes a trapezoid, but there is nothing

b

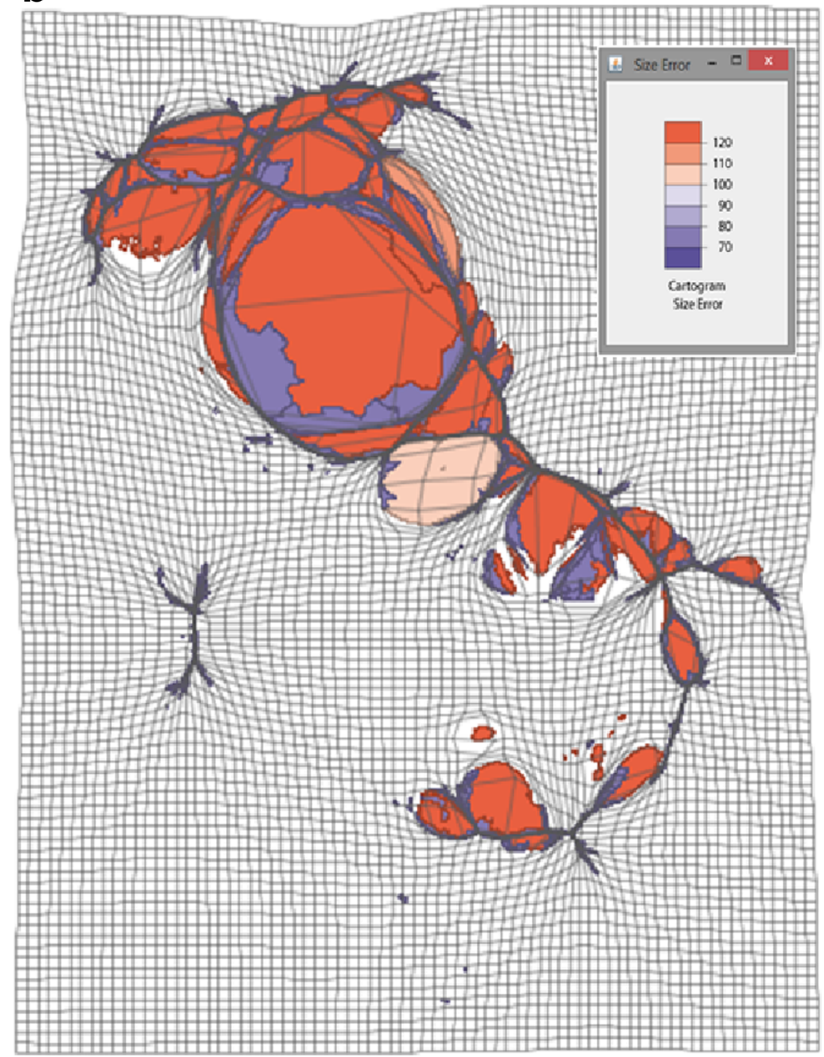

Fig. 3 a The places of the heart in Italy of the Decameron: a classical thematic map. b The places of the heart in Italy of the Decameron: an anamorphic chart 
Fig. 4 a The places of the heart in Boccaccio's world: a classical thematic map. $\mathbf{b}$ The places of the heart in Boccaccio's world: an anamorphic chart a

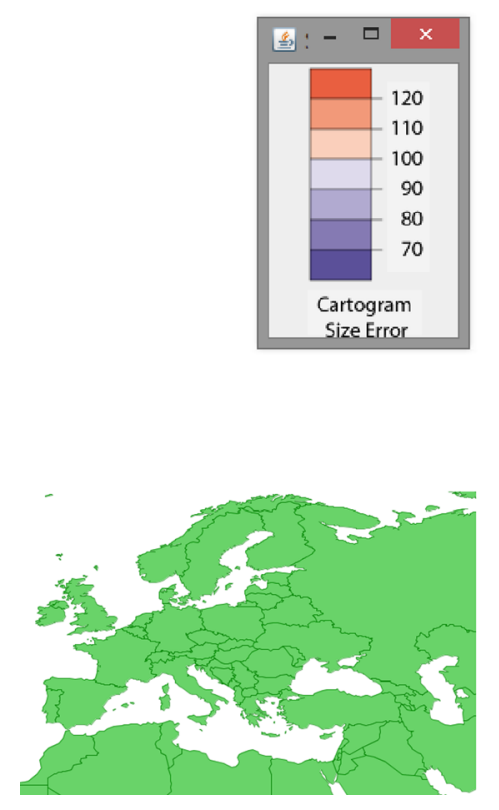

b

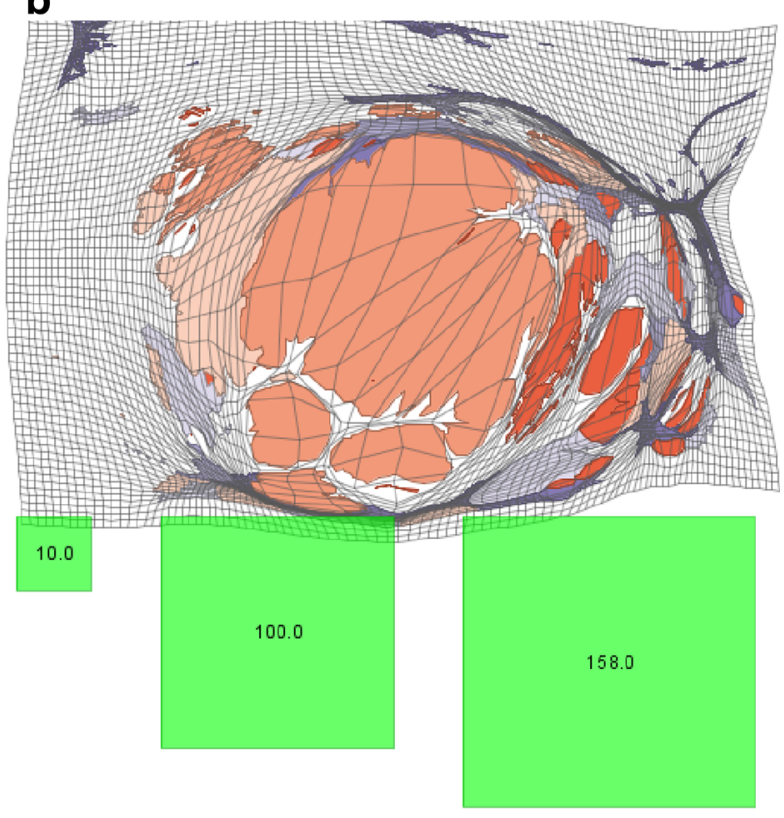

to stop a trapezoid appearing to be a square, by an inversion of the viewpoint (which is shifted to a position above the principal point, at an appropriate height, equal to the distance between the distance point and the principal point).

Once the principles have been calculated, a number of developments may follow, including specular, conical, or cylindrical anamorphosis. At any event, here we are dealing with images that, when viewed head on, are hard to understand and sometimes disturbing but which appear understandable and even harmonious when looked at from a specific angle.

Later, in the seventeenth century, Jean François Niceron, Marin Mersenne, and Emanuel Maignan, three scholars, monks of the Order of Minims, expert in optics and geometry and on good terms with Descartes, assert that what appears at first strange and fanciful is not due to chance or to supernatural phenomena, and that, furthermore, techniques used to record and describe and imitate the real world do not serve merely to represent reality, but also to reveal it (Fig. 8b).
According to Descartes, optical illusions can be constructed, as well as deconstructed and unmasked, by the laws of vision: indeed, the subject of illusion is at the heart of his thought.

For Niceron, anamorphosis is not merely a trick of the light, but rather a way to detect the presence of something hidden or unclear. La perspective curieuse (1638) and Thaumaturgus opticus (1646) are the masterpieces of this enfant prodige who, at the age of 18 , is already writing about Optics and who dies at only 33 years of age (Niceron 2009).

The first of these works begins with a description of the principles of perspective, starting with the first five regular solids, before proceeding to discuss more complex composite, irregular, or hollow solids.

Even more interesting is the part outlining the rules for producing images, which at first sight appear deformed but which acquire harmonic proportions when seen from a particular viewpoint (the first example is

Table 1 Table of speakers by day (columns) and order of narration

\begin{tabular}{|c|c|c|c|c|c|c|c|c|c|c|}
\hline & $1^{\mathrm{a}}$ & $2^{a}$ & $3^{\mathrm{a}}$ & $4^{\mathrm{a}}$ & $5^{\mathrm{a}}$ & $6^{\mathrm{a}}$ & $7^{\mathrm{a}}$ & $8^{\mathrm{a}}$ & $9^{\mathrm{a}}$ & $10^{\mathrm{a}}$ \\
\hline $1^{\mathrm{a}}$ & Panfilo & Neifile & Filostr. & Fiamm. & Panfilo & Filom. & Emilia & Neifile & Filom. & Neifile \\
\hline $2^{\mathrm{a}}$ & Neifile & Filostr. & Pamp. & Pamp. & Emilia & Pamp. & Filostr. & Panfilo & Elissa & Elissa \\
\hline $3^{\mathrm{a}}$ & Filom. & Pamp. & Filom. & Laur. & Elissa & Laur. & Elissa & Elissa & Filostr. & Filostr. \\
\hline $4^{\mathrm{a}}$ & Dioneo & Laur. & Panfilo & Elissa & Filostr. & Neifile & Laur. & Emilia & Neifile & Laur. \\
\hline $5^{\mathrm{a}}$ & Fiamm. & Fiamm. & Elissa & Filom. & Neifile & Panfilo & Fiamm. & Filostr. & Fiamm. & Emilia \\
\hline $6^{\mathrm{a}}$ & Emilia & Emilia & Fiamm. & Panfilo & Pamp. & Fiamm. & Pamp. & Filom. & Panfilo & Fiamm \\
\hline $7^{\mathrm{a}}$ & Filostr. & Panfilo & Emilia & Emilia & Laur. & Filostr. & Filom. & Pamp. & Pamp. & Pamp. \\
\hline $8^{\mathrm{a}}$ & Laur. & Elissa & Laur. & Neifile & Filom. & Emilia & Neifile & Fiamm. & Laur. & Filom. \\
\hline $9^{a}$ & Elissa & Filom. & Neifile & Filostr. & Fiamm. & Elissa & Panfilo & Laur. & Emilia & Panfilo \\
\hline $10^{\mathrm{a}}$ & Pamp. & Dioneo & Dioneo & Dioneo & Dioneo & Dioneo & Dioneo & Dioneo & Dioneo & Dioneo \\
\hline
\end{tabular}


Table 2 The same table with numerical values (according to the alphabetical order of the names of the speakers)

\begin{tabular}{cccccccccccc}
\hline & $1^{\mathrm{a}}$ & $2^{\mathrm{a}}$ & $3^{\mathrm{a}}$ & $4^{\mathrm{a}}$ & $5^{\mathrm{a}}$ & $6^{\mathrm{a}}$ & $7^{\mathrm{a}}$ & $8^{\mathrm{a}}$ & $9^{\mathrm{a}}$ & $10^{\mathrm{a}}$ & \\
\hline $1^{\mathrm{a}}$ & 10 & 8 & 6 & 4 & 10 & 5 & 3 & 8 & 5 & 8 & 67 \\
$2^{\mathrm{a}}$ & 8 & 6 & 9 & 9 & 3 & 9 & 6 & 10 & 2 & 2 & 64 \\
$3^{\mathrm{a}}$ & 5 & 9 & 5 & 7 & 2 & 7 & 2 & 2 & 6 & 6 & 51 \\
$4^{\mathrm{a}}$ & 1 & 7 & 10 & 2 & 6 & 8 & 7 & 3 & 8 & 7 & 59 \\
$5^{\mathrm{a}}$ & 4 & 4 & 2 & 5 & 8 & 10 & 4 & 6 & 4 & 3 & 50 \\
$6^{\mathrm{a}}$ & 3 & 3 & 4 & 10 & 9 & 4 & 9 & 5 & 10 & 4 & 61 \\
$7^{\mathrm{a}}$ & 6 & 10 & 3 & 3 & 7 & 6 & 5 & 9 & 9 & 9 & 67 \\
$8^{\mathrm{a}}$ & 7 & 2 & 7 & 8 & 5 & 3 & 8 & 4 & 7 & 5 & 56 \\
$9^{\mathrm{a}}$ & 2 & 5 & 8 & 6 & 4 & 2 & 10 & 7 & 3 & 10 & 57 \\
$10^{\mathrm{a}}$ & 9 & 1 & 1 & 1 & 1 & 1 & 1 & 1 & 1 & 1 & 18 \\
& 55 & 55 & 55 & 55 & 55 & 55 & 55 & 55 & 55 & 55 & 550 \\
\hline & & & & & & & & & & &
\end{tabular}

a chair). Lastly, catoptric anamorphosis is described (images viewed in a mirror), together with elements of Dioptrics.

Figures of saints on the walls of the Minim monastery in Paris, at times hard to perceive, viewed from a different angle, suddenly reveal their magnificence and remind us of worldly vanity (Baltrušaitis 1978).

Matters regarding the illusion of the senses captivated Descartes just as they had Plato. In his "Discourse on the Method," the former says "I have ever remained firm in my original resolution ...to accept as true nothing that did not appear to me more clear and certain than the demonstrations of the Geometers had formerly appeared."

At a certain point, in the "Dioptrique," Descartes observes that, when one holds a little ball between

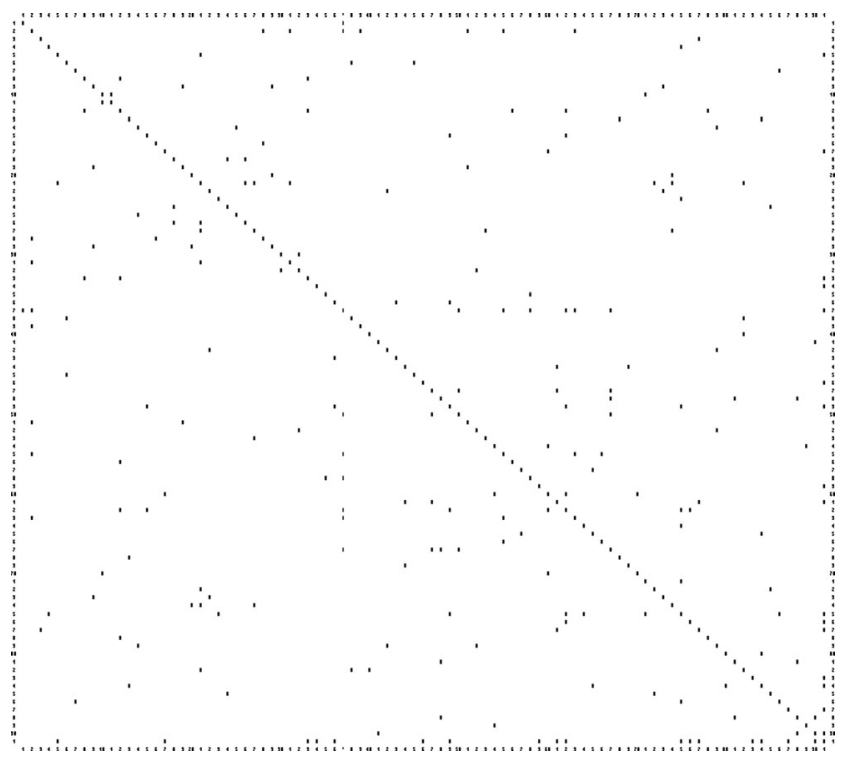

Fig. 5 Connection (alphabetical) matrix

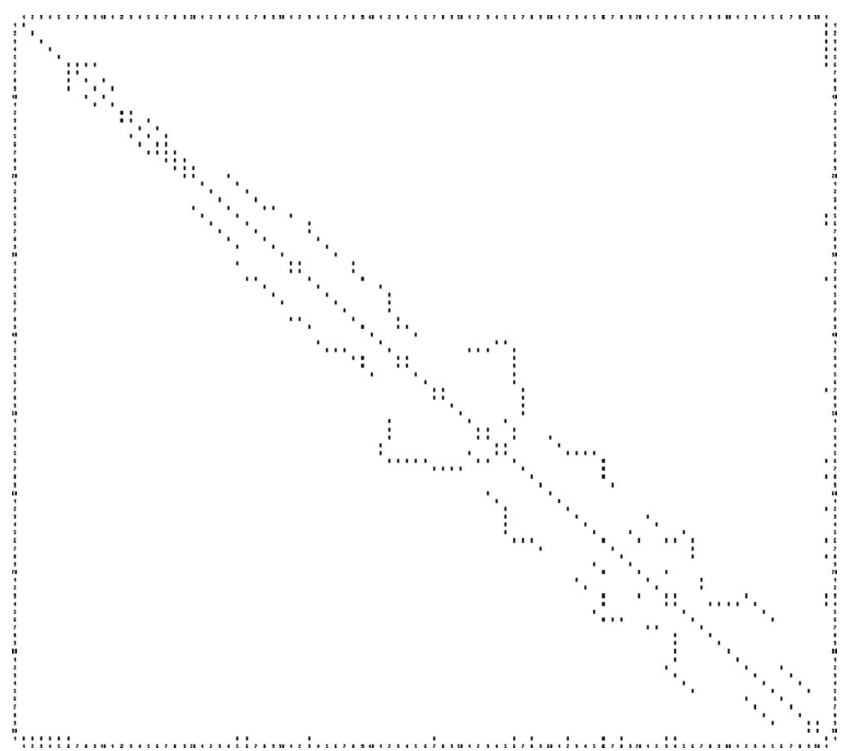

Fig. 6 Connection reordered matrix

crossed fingers, our senses deceive us, making us believe there are two balls; he also finds other cases of the senses being tricked (distorted images, too, deceive when not viewed from the correct angle).

Both painters and philosophers are wont to reflect upon illusion and truth, and consequently we have many (totally or partially) anamorphic pictures.

As an example, we present a portrait of Edward VII of England, clearly distorted by anamorphosis, to be compared with the normal proportions, when seen from the right viewpoint (Fig. 7).

"The Ambassadors," a famous painting by Holbein (Fig. 8a), shows two French ambassadors, standing and looking to the front, leaning against the upper of two shelves, on which a celestial globe, some astronomical instruments, a book, and a sundial are to be seen, while on the lower shelf there is a terrestrial globe, a square and compass, two books, and a lute. These objects symbolize the liberal arts, from astronomy to geometry, from mathematics to music, but, at the same time, evoke the art of perspective, since they feature regularly in treatises on perspective. At the bottom right, a strange object lies on the floor: it is a skull, recognizable as such, however, from a single viewpoint alone. The anamorphic image of the skull (which completes the evocation of perspective already seen in the aforementioned objects) represents the vanity of the arts, of the sciences, of power, and is in keeping with the Nordic tradition of the "Triumph of Death."

However, anamorphosis can also be used for playful ends (mainly, the spherical and cylindrical ones), such as for Chinese illusionist tricks. 
Fig. 7 William Scrott (1546): anamorphic portrait of Edward VI of England (London, National Gallery)
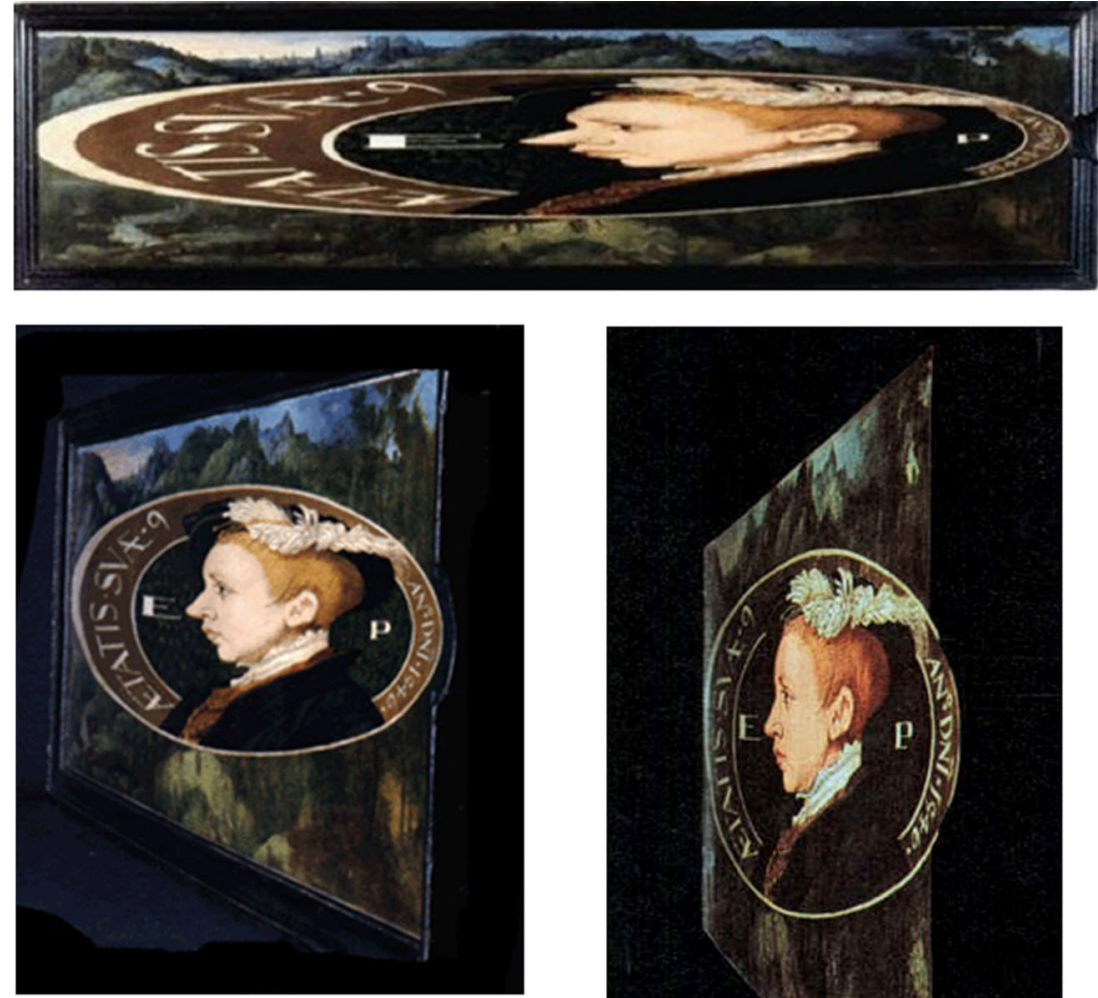

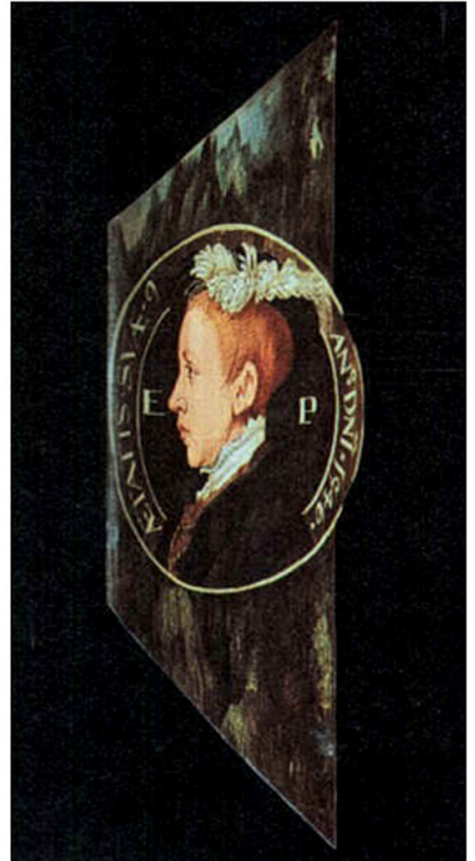

\section{Appendix 2: Boccaccio's geography: places and travels of the Decameron novels 10}

\section{1st day}

1st tale: Prato, Paris, Burgundy, Tuscany

2nd tale: Paris, Rome, Paris

3rd tale: Babylon, Alexandria

4th tale: Lunigiana

5th tale: Monferrato, Genoa, France, Genoa

6th tale: Florence

7th tale: Paris, Cluny, Verona, Paris

8th tale: Genoa

9th tale: Gascony, the Holy Land, Cyprus

10th tale: Bologna

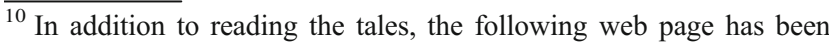
consulted: http://it.wikipedia.org/wiki/Struttura_del_Decameron.
}

\section{2nd day}

1st tale: Treviso, Florence

2nd tale: Asti, Bologna, Ferrara, Castel Guglielmo (province of Rovigo), Verona

3rd tale: Florence, England and London (with several returns to Florence), Florence, Rome, Bruges, Florence, Paris, England and Cornwall, Florence, Scotland

4th tale: Reggio Calabria, Gaeta, Salerno, Ravello, Amalfi, Cyprus, Aegean Sea, Sea of Constantinople, Kefalonia, Island of Gurfo (present-day Corfu), Brindisi, Trani

5th tale: Perugia, Naples, Sicily, Palermo, Agrigento, Perugia (with several returns to Sicily), Naples, Perugia

6th tale: Sicily, Benevento, Naples, Lipari, Ponza, Mouth of the Magra and Lunigiana, Genoa, Alexandria, Sicily and Palermo, Lerici

7th tale: Babylon, Gharb, Alexandria, Sardinia, Majorca, Peloponnese (Chiarenza, Empire of Romania), Athens, Aegina, Chios, Smyrna, Cappadocia, Rhodes, Cyprus with Paphos and Famagusta, Armenia, Jerusalem, Alexandria, Crete, Acquamorta (present-day Monte di Procida), Borgo San Lorenzo 
Fig. 8 a Hans Holbein (1533):

The Ambassadors (London,

National Gallery). b Jean

François Niceron (1635): portrait

of Luis XII (Rome, Palazzo

Barberini) a

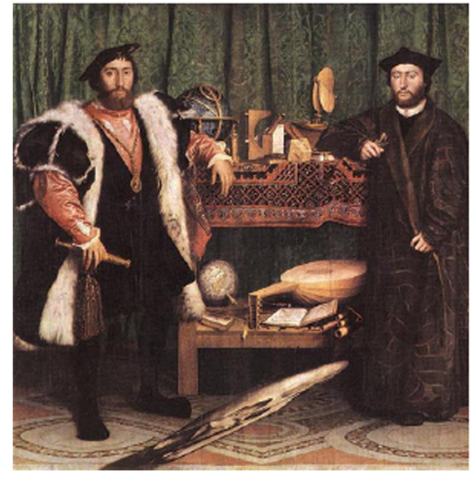

b

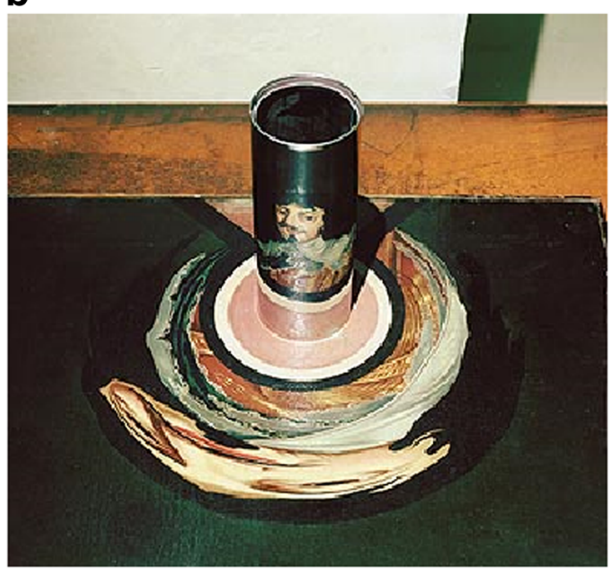

8th tale: Antwerp, Calais, London, Stanford, Wales, Ireland, London, Paris

9th tale: Paris Genoa, Albissola, Acre, Alexandria

10th tale: Pisa, Ravenna, Leghorn, Monaco, Pisa

\section{3rd day}

1st tale: Florence, Lamporecchio (province of Pistoia)

2nd tale: Pavia, Lombardy

3rd tale: Florence, Genoa

4th tale: Florence, Paris

5th tale: Pistoia, Milan

6th tale: Naples

7th tale: Florence, Ancona, Cyprus, Lunigiana and

Pontremoli

8th tale: Tuscany, Purgatory (as believed, being alive)

9th tale: Narbonne, Paris, Montpellier, Roussillon, Florence

10th tale: Barbary (modern-day Tunisia) with Capsa, deserts of Thebais (Egypt)

\section{4th day}

1st tale: Salerno

2nd tale: Imola, Venice, Assisi, Flanders

3rd tale: Provence and Marseilles, Spain, Crete and Candia, Rhodes

4th tale: Sicily, Barbary (modern-day Tunisia) with Tunis and Carthage, Sardinia, Granada, Messina, Ustica

5th tale: Messina, Naples

6th tale: Brescia

7th tale: Florence

8th tale: Florence, Paris

9th tale: Provence

10th tale: Salerno, Amalfi

\section{5th day}

1st tale: Cyprus, Rhodes, Crete

2nd tale: Lipari, Tunis, Sousse (in Tunisia), Granada

3rd tale: Rome, Anagni, Rome

4th tale: Valbona (hamlet of Berceto, province of Parma or

of Collagno, province of Reggio Emilia)

5th tale: Pavia, Cremona, Romagna and Faenza, Fano

6th tale: Procida, Scalea, Ischia, Palermo

7th tale: Trapani, Armenia, Trapani, Rome

8th tale: Ravenna, Classe (province of Ravenna), Hell,

Ravenna

9th tale: Tuscany, Campi Bisenzio, Florence

10th tale: Perugia

\section{6th day}

1st tale: Florence

2nd tale: Rome, Florence

3rd tale: Florence, Barcelona

4th tale: Florence, Venice

5th tale: Mugello, Florence

6th tale: Florence

7th tale: Prato

8th tale: Florence

9th tale: Florence

10th tale: Certaldo, Venice, Florence, (imaginary) lands of

Truffia, Buffia, and Menzogna, Abruzzo region, India, Florence

\section{7th day}

1st tale: Florence, Fiesole, Florence

2nd tale: Naples

3rd tale: Siena

4th tale: Arezzo 
5th tale: Rimini

6th tale: Florence

7th tale: Paris, Bologna

8th tale: Florence

9th tale: Argos (Peloponnese)

10th tale: Siena, Hell

\section{8th day}

1st tale: Prato, Milan, Genoa

2nd tale: Alexandria, Avignon, Florence

3rd tale: Florence, Berlinzone (the imaginary Land of

Bengodi), Faenza

4th tale: Fiesole

5th tale: Florence

6th tale: Florence

7th tale: Paris, Florence, Valdarno, Paris

8th tale: Siena

9th tale: Florence, Forlimpopoli, Laterina (province of

Arezzo), Bologna

10th tale: Palermo, Salerno, Monaco, Naples, Florence,

Ferrara

\section{9th day}

1st tale: Florence, Pistoia

2nd tale: Lombardy

3rd tale: Florence

4th tale: March of Ancona, Buonconvento (province of

Siena), Siena, Torrenieri (hamlet of Montalcino), Corsignano (hamlet of Pienza)

5th tale: Florence, Camaldoli, Florence

6th tale: Florence, Romagna, Florence

7th tale: Molese (the area of Mola di Bari), Florence

8th tale: Florence 9th tale: Jerusalem, Antiochia, Lajazzo (today Ayas in Turkey)

10th tale: Barletta, Tresanti (province of Florence), Bitonto

Open Access This article is distributed under the terms of the Creative Commons Attribution 4.0 International License (http:// creativecommons.org/licenses/by/4.0/), which permits unrestricted use, distribution, and reproduction in any medium, provided you give appropriate credit to the original author(s) and the source, provide a link to the Creative Commons license, and indicate if changes were made.

\section{References}

Baltrušaitis J (1978) Anamorfosi. Adelphi, Milano

Boccaccio G (2012) Il Decamerone. Giovanni Salani Ed., Firenze/ Mondadori - Oscar classici, Milano

Branca V (1992) Una chiave di lettura per il «Decameron». In G. Boccaccio, Decameron. Torino, Einaudi

Gastner M.T., Newman M.E.J. (2004) Diffusion-based method for producing density-equalizing maps. Proceedings of the National Academy of Sciences of the United States of America. Vol.101 n.2

George A, Liu JWH (1981) Computer solution of large sparse positive definite systems. Prentic e Hall, Englewood Cliffs (NJ)

Greppi C (2010) Il dizionario geografico di Boccaccio. Luoghi e paesaggi nel De montibus. Boccaccio geografo. A cura di Roberta Morosini. Mauro Pagliai, In

Gombrich E (1979) La storia dell'arte raccontata da Ernst gombrich. Einaudi, Torino

Kemp M (1999) Immagine e verità. Il Saggiatore, Milano

Lomazzo GP (1973) Scritti sulle arti, a cura di R. P. Ciardi, Firenze

Markov AA. (1913) An example of statistical investigation of the text Eugene Onegin concerning the connection of samples in chains. (In Russian.) Bulletin of the Imperial Academy of Sciences of St. Petersburg

Niceron JF (2009) La perspective curieuse du Reverend P.Niceron Minime (1652). Kessinger Publishing, Whitefish-Montana

Odifreddi P (2011) Una via di fuga. Mondadori, Milano

Panofsky E (1991) La prospettiva come forma simbolica. Fertrinelli, Milano

Tobler W (1996) Thirty five years of computer cartograms. Annals, Association of American geographers 